\title{
Chitosan: Effect of a New Chelating Agent on the Microhardness of Root Dentin
}

\author{
Josilaine Amaral PIMENTA \\ Danilo ZAPAROLLI \\ Jesus Djalma PÉCORA \\ Antonio Miranda CRUZ-FILHO \\ Department of Restorative Dentistry, Ribeirão Preto Dental School, \\ USP - University of São Paulo, Ribeirão Preto, SP, Brazil
}

\begin{abstract}
The effect of solutions of $0.2 \%$ chitosan, $15 \%$ EDTA and $10 \%$ citric acid on the microhardness of root dentin was evaluated comparatively in this study. Thirteen sound human maxillary central incisors were selected and decoronated at the cementoenamel junction. Ten roots were set into rapid polymerization acrylic resin and the root/resin block was fitted to the cutting machine to obtain slices from the cervical third. The first slice was discarded and the second slice was divided into four quadrants. Each quadrant was used to construct a sample, so that 4 specimens were obtained from each root slice, being one for each chelating solution to be tested: $15 \%$ EDTA, $10 \%$ citric acid, $0.2 \%$ chitosan and distilled water (control). The specimens were exposed to $50 \mu \mathrm{L}$ of the solution for $5 \mathrm{~min}$, and then washed in distilled water. A microhardness tester (Knoop hardness) with a $10 \mathrm{~g}$ load was used for $15 \mathrm{~s}$. Data were analyzed statistically by one-way ANOVA and Tukey-Kramer test $(\alpha=0.05)$. The other 3 roots had the canals instrumented and irrigated at the end of the biomechanical preparation with the test solutions, and then examined by scanning electron microscopy (SEM) for qualitative analysis. All solutions reduced the microhardness of root dentin in a way that was statistically similar to each other $(p>0.05)$ but significantly different from the control $(p>0.05)$. The SEM micrographs showed that the three solutions removed smear layer from the middle third of the root canal. In conclusion, $0.2 \%$ chitosan, $15 \%$ EDTA and 10\% citric acid showed similar effects in reducing dentin microhardness.
\end{abstract}

Key Words: microhardness, EDTA, chitosan, chelating agent.

\section{INTRODUCTION}

The goal of cleaning the root canal system is to eliminate aggressive and irritating agents such as microorganisms, their products and vital and necrotic pulp tissue remnants (1). Endodontic instrumentation, using manual or mechanized techniques, produces smear layer on the root canal walls and smear plugs into dentinal tubules. A systematic review and meta-analysis of leakage studies concluded that the removal of the smear layer improves the fluid tight seal of the root canal system (2). The smear layer can be removed using different solutions, but the most commonly employed method uses varied concentrations of EDTA combined with sodium hypochlorite (1). The demineralizing effect of EDTA acts concurrently and indistinguishably on the smear layer and root dentin, with consequent exposure of collagen and reduction of dentin microhardness (3-5).

Sayin et al. (6) verified that the use of EDTA, either alone or combined with sodium hypochlorite, reduces the microhardness of root dentin significantly. The reducing effect of EDTA can be felt in the first min of use, and is directly proportional to the time of application (7).

Another chelating agent used for removing the smear layer from root canals is citric acid. This agent is a weak organic acid with a less cytotoxic effect than EDTA. Prior studies have shown that citric acid removes calcium ions efficiently from the dentin (8). However, in relation to the effect on dentinal microhardness, it has been reported (3) that $10 \%$ citric acid is less efficient than 17\% EDTA in 1-, 3- and 5-min periods of action.

Correspondence: Prof. Dr. Antonio Miranda Cruz-Filho, Departamento de Odontologia Restauradora, Faculdade de Odontologia de Ribeirão Preto, USP, Avenida do Café, S/N, 14040-904 Ribeirão Preto, SP, Brasil. Tel: +55-16-3602-4792. Fax: +55-16-3633-0999. e-mail: cruz@forp. usp.br 
It is known clinically that reduction of root dentin microhardness facilitates the introduction of instruments in cases of narrow canals, in addition to favoring the excision of dentin during the biomechanics of the teeth in general.

Chitosan is a natural polysaccharide, prepared by the deacetylation of chitin, which is obtained from the shells of crabs and shrimps (9). This polysaccharide is endowed with properties of biocompatibility, biodegradibility, bioadhesion and atoxicity to human cells (10). After cellulose, it is the most abundant substance in nature, making its use ecologically interesting (11). It also presents low cost, in addition to a high chelating capacity for different metallic ions (9). The purpose of the present study was to evaluate comparatively the action of $0.2 \%$ chitosan, $15 \%$ EDTA and $10 \%$ citric acid on root dentin microhardness.

\section{MATERIAL AND METHODS}

This project was developed in accordance with the institutional Ethics Committee (Protocol \#2011.1.370.58.7). Thirteen extracted human maxillary central incisors were selected based on their relative dimensions and similarity in morphology. Surfaceadhered soft tissue debris were removed with a brush, and the teeth were stored in $0.1 \%$ thymol at $9^{\circ} \mathrm{C}$. Teeth with caries, cracks, and dilacerations were excluded.

All teeth were decoronated at the cementoenamel junction with a water-cooled carborundum disk at high-speed and the pulp tissue was extirpated using a barbed broach (Dentsply Ind. e Com. Ltda., Petrópolis, RJ, Brazil). Next, 10 roots were embedded in autopolymerizing acrylic resin using silicone molds, and the root/resin blocks were taken to a precision cutting machine (Struers A/S, Copenhagen, Denmark) for cross-sectioning of the cervical portion.

Three 1-mm-thick dentin slices were obtained from each root. The first (outer) slices were discarded and the second (middle) slices were used. Each slice was divided into 4 quadrants using a \#15 scalpel blade. Each quadrant was used to construct a sample, so that 4 specimens were obtained from each root slice, being one for each chelating solution to be tested, forming 4 groups ( $\mathrm{n}=10$ specimens per solution): $15 \% \mathrm{EDTA}$ ( $\mathrm{pH}$ 7.3 ), $10 \%$ citric acid ( $\mathrm{pH} 2.04), 0.2 \%$ chitosan ( $\mathrm{pH} 3.2$ ) and distilled water (control). The $0.2 \%$ chitosan solution was prepared with $0.2 \mathrm{~g}$ of chitosan (ACROS Organics Geel, Belgium; degree of deacetylation $>90 \%$ ) in 100
$\mathrm{mL}$ of $1 \%$ acetic acid. The mixture was agitated using a magnetic agitator for $2 \mathrm{~h}$.

Each quadrant of the root slices had its coronal side coated with liquid vaseline and was put in the center of a metallic ring fixed on a red wax plate, which was filled with autopolymerizing acrylic resin. The test surface was ground wet with 400-, 500- and 600-grit silicon carbide paper in a polishing machine (Arotec, São Paulo, SP, Brazil) followed by hand polishing with felt disc embedded with aluminum oxide paste (Arotec).

A standardized volume of $50 \mu \mathrm{L}$ of each chelating solution was delivered on the test surface of each specimen using an automated micropipette. The control group was treated with distilled water. After $5 \mathrm{~min}$, the specimens were rinsed with $20 \mathrm{~mL}$ of $1 \%$ sodium hypochlorite to remove any residues of the test solution. The specimens were then subjected to the microhardness test of root dentin using a Knoop hardness tester (Shimadzu HMV-2000; Shimadzu Corporation, Kyoto, Japan), with a load of $10 \mathrm{~g}$ for 15 $\mathrm{s}$. Indentations were made from the dentin close to the canal lumen following a straight line toward the dentin adjacent to the cement. Three indentations were made at a distance of $200 \mu \mathrm{m}$ from each other. The indentations were viewed on the computer screen connected to the microhardness meter. The average length of the two diagonals was used to calculate the microhardness value (KHN). The representative hardness value for each specimen was obtained as the average of the results for the three indentations. Data were analyzed statistically by ANOVA and Tukey's multiple-comparison test at a significance level of $5 \%$.

The canals of the other 3 roots were prepared according to the crown-down technique with nickel-titanium instruments (Quantec; Sybronendo Corporation, West Collins, Orange, CA, USA) activated by an electric engine (X-Smart; Dentsply Maillefer, Ballaigues, Switzerland). At each change of instrument, the canals were irrigated with $1 \mathrm{~mL}$ de $1 \%$ sodium hypochlorite, and filled with $5 \mathrm{~mL}$ of the test solution for $3 \mathrm{~min}$ as a final irrigant. Next, the specimens were prepared for analysis by scanning electron microscopy (SEM) to evaluate the cleanliness of the middle third. Two diametrically opposed grooves were made in the teeth using metallic discs under cooling and a bi-bevel chisel. The roots were split lengthwise. The half with fewer irregularities, which best represented total root canal length, was selected.

The specimens were measured individually 
using a digital caliper to demarcate the root thirds. The area referring to half of the middle third was used for the analysis. SEM micrographs at $\times 350$ magnification, referring to the middle root thirds were obtained using a scanning electron microscope (JSM5410; JEOL, Tokyo, Japan).

\section{RESULTS}

Figure 1 shows a graphic representation of the two-by-two group comparisons of Knoop microhardness mean values and respective levels of significance.

The groups treated $0.2 \%$ chitosan $(24.5 \pm 6.5)$, $15 \% \operatorname{EDTA}(24.4 \pm 7.0)$ and $10 \%$ citric acid $(19.3 \pm 4.4)$ reduced dentin microhardness in a statistically similar $(\mathrm{p}>0.05)$ manner to each other, but different significantly from the control $(36.9 \pm 6.9)(\mathrm{p}<0.01)$.

The qualitative analysis of the SEM micrographs revealed that all chelating solutions removed smear layer from the middle third of the root canals, leaving visible, open dentinal tubules (Fig. 2).

\section{DISCUSSION}

The results of this study indicated that chitosan, EDTA and citric acid reduced root canal microhardness with no statistically significant difference among the solutions. Currently, the combined use of EDTA and sodium hypochlorite is the most widely used by endodontists to remove the smear layer from root canals $(12,13)$. However, the search for more biocompatible solutions than EDTA to minimize the aggression to the periapical tissues has increased over the years.

The use of weak acids, such as citric and lactic acids and apple cider vinegar, has been investigated (1315). Citric acid is an organic acid found in citrus fruits, which readily reacts with calcium, forming calcium citrate (16). Previous studies have shown that citric acid has the property of removing calcium ions from dentin more efficiently than $\operatorname{EDTA}(3,8)$, in addition to being more biocompatible $(17,18)$. Machado-Silveiro et al. (8) reported that $1 \%$ and $10 \%$ citric acid promoted greater decalcification of dentinthan $17 \%$ EDTA and $10 \%$ sodium citrate.

Chitosan, derived from chitosin, is a polysaccharide endowed with biocompatibility (10) and chelating capacity (9).

In the present study, $0.2 \%$ chitosan reduced dentin microhardness similarly to $15 \%$ EDTA and $10 \%$ citric acid. Cruz-Filho et al. (19) has recently evaluated the chelating capacity of different substances on root canal lumen dentin. Among the substances evaluated, 15\%

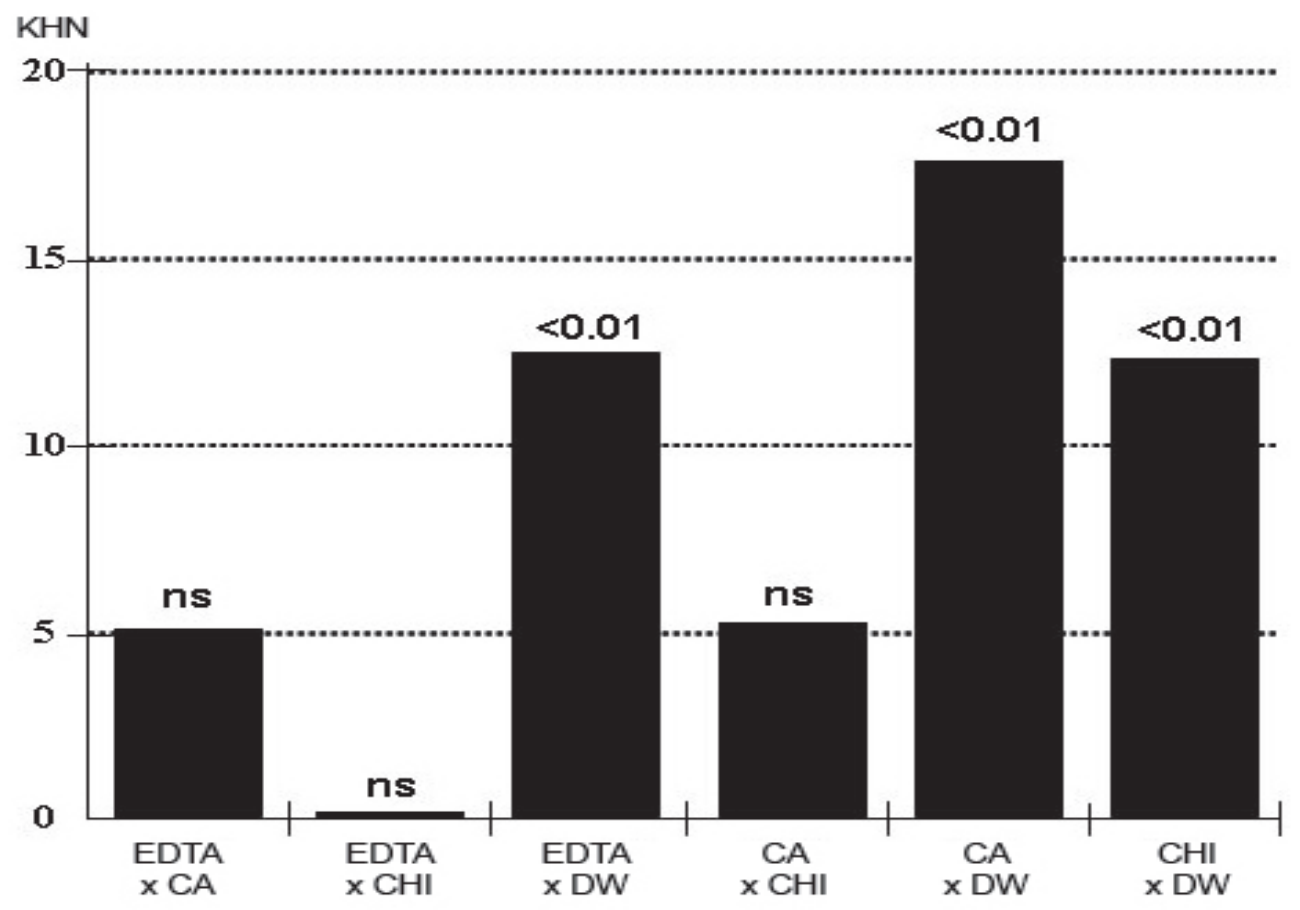

Figure 1. Two-by-two group comparisons of Knoop microhardness mean values and level of significance. 

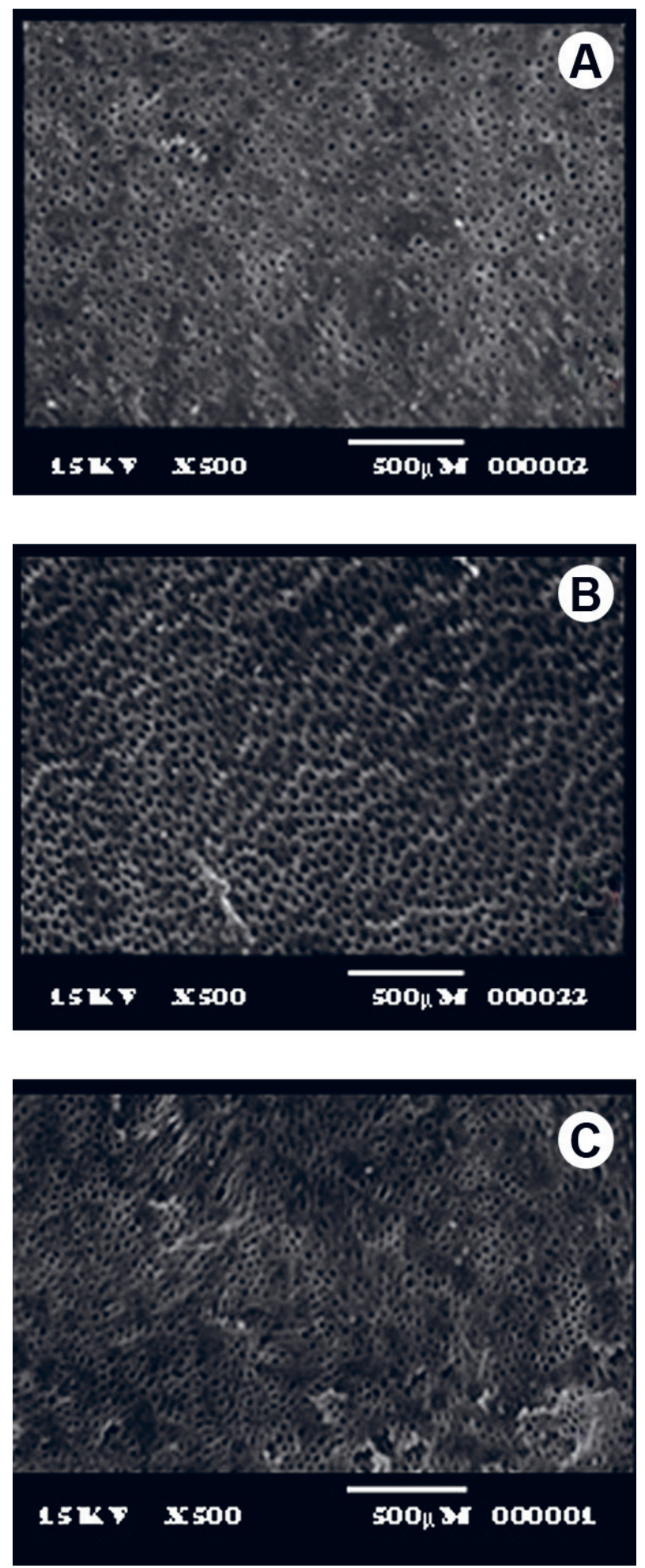

Figure 2. SEM micrographs of the middle root canal third $(\times 500)$. A: smear-free surface with open dentinal tubules after treatment with $15 \%$ EDTA; B: group treated with $10 \%$ citric acid, showing complete removal of smear layer; $\mathrm{C}$ : smear-free surface with open dentinal tubules and preserved intertubular dentin after treatment with $0.2 \%$ chitosan.
EDTA and $10 \%$ citric acid promoted greater reduction in microhardness. Both solutions acted similarly, supporting the results of the present study. However, Eldeniz et al. (20) reported that $19 \%$ citric acid is more efficient in reducing dentin microhardness than $17 \%$ EDTA, which differs from our results. The efficiency of chelating agents depends on several factors, such as time of application, $\mathrm{pH}$, concentration of the solution, and amount of solution $(1,7,21)$. The concentration of citric acid used by Eldeniz et al. (20) is almost two times that of the present study, which probably intensified the demineralizing action of this solution. The chelating effect of citric acid increases with the increase of its concentration (22).

The use of chitosan at $0.2 \%$ concentration in the present study is justified by preliminary tests in which the comparison between the substance prepared with different concentrations and action times on dentin showed that application of the $0.2 \%$ concentration for 5 min was the most viable combination for use on the root dentin. The similar chelating effect of $0.2 \%$ chitosan compared to the other tested solutions, allied to its advantageous properties already and low concentration, indicate that this chelating solution should be preferred for dentin decalcification. The fact that EDTA acts efficiently to reduce dentinal microhardness is due to its chelating property. Among the theories that try to explain this chemical reaction is that the crystalline field, which maintains the force of attraction between the central metal and ligands, is purely electrostatic. Thus, the metallic ion exerts an attracting force that is greater than the repulsion created by the atoms of the EDTA molecule (1). In relation to chitosan, despite not fully knowing its mechanism of action, it is believed that adsorption, ionic exchange and chelation are responsible for the formation of complexes between the substance and the metallic ions. The type of interaction that occurs depends on the ion involved, the chemical structure of chitosan, and the $\mathrm{pH}$ of the solution (23). Currently, there are two versions that try to explain the chelation process of chitosan. The first, known as the model of the bridge, is grounded in the theory that two or more amino groups of one chitosan chain will bind to the same metallic ion (24). The other defends the thesis that only one amino group of the structure of the substance is involved in the binding, that being the metallic ion "anchored" to the amino group (25). Anyway, the mechanism of chelation of calcium ions in dentin might also be responsible for the depletion of the inorganic portion of the smear layer, 
as observed in the SEM micrographs. Particularly the group treated with chitosan presented patent dentinal tubules without alteration of the intertubular dentin.

As described in the Material and Methods section, chitosan was diluted in $1 \%$ acetic acid for preparation of the solution. Thus, it could be speculated the chelating effect observed in this study would be due to the acid and not of chitosan. However, previous studies have shown that the capacity of $5 \%$ acetic acid for reducing dentin microhardness, removing the smear layer and chelating calcium ions in the root canal is insignificant in relation to $15 \%$ EDTA and $10 \%$ citric acid $(13,19)$. In this way, it is highly evident that the effect caused by chitosan on dentin microhardness is due exclusively to the substance and not to the acid. Prior to the clinical use of a new substance or product, further studies are needed to investigate in detail its physical, chemical and biological properties in order to verify the benefits and consequences to humans.

In conclusion, the present in vitro results demonstrated that there were no significant differences among $0.2 \%$ chitosan, $15 \%$ EDTA and $10 \%$ citric acid solutions in the reduction of root dentin microhardness. Distilled water, which was used as a control, did not alter the microhardness.

\section{RESUMO}

Avaliou-se o efeito das soluções de quitosana $0,2 \%$, EDTA $15 \%$ e ácido cítrico $10 \%$ sobre a microdureza da dentina radicular. Foram utilizados 13 incisivos centrais superiores humanos, os quais tiveram suas coroas seccionadas transversalmente e desprezadas. Dez raízes foram incluídas em resina acrílica de rápida polimerização e o bloco formado raiz/resina adaptado à maquina de corte. Desprezou-se o primeiro corte transversal da porção cervical e dividiu-se o segundo, em 4 quadrantes. Cada quarto foi destinado à confecção do corpo-de-prova obtendo-se 4 espécimes para cada raiz, um para cada solução $(n=10)$ : EDTA a $15 \%$, ácido cítrico a $10 \%$, quitosana a $0,2 \%$ e água destilada (controle). Os espécimes receberam $50 \mu \mathrm{L}$ da solução por $5 \mathrm{~min}$, sendo em seguida, lavados com água destilada. Utilizou-se um microdurômetro (dureza Knoop) com carga de 10 g durante $15 \mathrm{~s}$. Os dados foram avaliados por meio do teste ANOVA e Tukey-Kramer $(\alpha=0,05)$. Três incisivos centrais superiores foram instrumentados e irrigados, ao final da biomecânica, com uma das soluções estudadas. Os espécimes foram levados para MEV e posterior análise qualitativa. Todas as soluções avaliadas reduziram a microdureza da dentina radicular de forma semelhante entre si $(p>0,05)$ e estatisticamente diferente do controle $(p<0,01)$. As fotomicrografias mostraram que as 3 soluções removeram a smear layer do terço médio do canal radicular. Concluiu-se que as soluções de quitosana $0,2 \%$, EDTA $15 \%$ e ácido cítrico $10 \%$ apresentam efeito semelhante na redução da microdureza dentinária.

\section{ACKNOWLEDGEMENTS}

The authors acknowledge the Brazilian federal funding agency CAPES for the financial support to the study.

\section{REFERENCES}

1. Hüslmann M, Heckendorff M, Lennon A. Chelating agents in root canal treatment: mode of action and indications for their use. Int Endod J 2003;36:810-830.

2. Shahravan A, Haghdoost AA, Adl A, Rahimi H, Shadifar F. Effect of smear layer on sealing ability of canal obturation: a systematic review and meta-analysis. J Endod 2007;33:96-105.

3. De-Deus G, Paciornik S, Mauricio MHP. Evaluation of the EDTA, EDTAC and citric acid on the microhardness of root dentine. Int Endod J 2006;39:401-407.

4. De-Deus G, Zehnder M, Reis C, Fidel S, Fidel RAS, Galan Jr $\mathrm{J}$, et al.. Longitudinal co-site optical microscopy study on the chelating ability of etidronate and EDTA using a comparative single-tooth model. J Endod 2008;34:71-75.

5. Akcay I, Sen BH. The effect of surfactant addition to EDTA on microhardness of root dentin. J Endod 2012;5,704-707.

6. Sayin TC, Serper A, Cehreli ZC, Otlu HG. The effect of EDTA, EGTA, EDTAC and tetracycline- $\mathrm{HCl}$ with and without subsequent $\mathrm{NaOCl}$ treatment on the microhardness of root canal dentin. Oral Surg Oral Med Oral Pathol Oral Radiol Endod 2007;104:418-424.

7. Cruz-Filho AM, Silva RG, Pécora JD. Accion del EDTAC em la microdureza de la dentina radicular em diferentes tiempos de aplicación. Rev Odont Fed Lat Amer 1996;2:82-90.

8. Machado-Silveiro LF, González-López S, González-Rodríguez MP. Decalcification of root canal dentine by citric acid, EDTA and sodium citrate. Int Endod J 2004;37:365-369.

9. Kurita K. Chemistry and application of chitin and chitosan. Polym Degrad Stab 1998;59:117-120.

10. Akncbay H, Senel S, Ay ZY. Application of chitosan gel in the treatment of chronic periodontitis. J Biomed Mater Res B Appl Biomater 2007;80:290-296.

11. Peter MG. Applications and environmental aspects of chitin and chitosan. J Macromol Sci 1995;A32:629-640.

12. Marques AAF, Marchesan MA, Sousa-Filho CB, Silva-Sousa YTC, Sousa-Neto MD, Cruz-Filho AM. Smear layer removal and chelated calcium ion quantification of three irrigating solutions. Braz Dent J 2006;17:306-309.

13. Spanó JCE, Silva RG, Guedes DFC, Sousa-Neto MD, Estrela C, Pécora JD. Atomic absorption spectrometry and scanning electron microscopy evaluation of concentration of calcium ions and smear layer removal with root canal chelators. J Endod 2009;35:727-730.

14. Dineshkumar MK, Vinothkumar TS, Arathi G, Shanthisree P, Kandaswamy D. Effect of ethylene diamine tetra-acetic acid, MTAD, and HEBP as a final rinse on the microhardness of root dentin. J Conserv Dent 2012;15:170-173.

15. Prado M, Gusman H, Gomes BPFA, Simão RA. Scanning electron microscopic investigation of the effectiveness of phosphoric acid in smear layer removal when compared with EDTA and citric acid. J Endod 2011;37:255-258.

16. Papagianni M. Advances in citric acid fermentation by Aspergillus niger: biochemical aspects, membrane transport and modeling. Biotechnol Adv 2007;25:244-263.

17. Scelza MF, Teixeira AM, Scelza P. Decalcifying effect of EDTA-T, $10 \%$ citric acid, and 17\% EDTA on root canal dentin. 
Oral Surg Oral Med Oral Pathol Oral Radiol Endod 2003;95:234236.

18. Pérez-Heredia M, Ferrer-Luque CM, González-Rodríguez MP, Martín-Peinado FJ, González-López S. Decalcifying effect of $15 \%$ EDTA, $15 \%$ citric acid, $5 \%$ phosphoric acid and $2.5 \%$ sodium hypochlorite on root canal dentine. Int Endod J 2008;41:418-423.

19. Cruz-Filho AM, Sousa-Neto MD, Savioli RN, Silva RG, Vansan LP, Pécora JD. Effect of chelating solutions on the microhardness of root canal lumen dentin. J Endod 2011;37:358-362.

20. Eldeniz AU, Erdemir A, Belli S. Effect of EDTA and citric acid solutions on the microhardness and the roughness of human root canal dentin. J Endod 2005;31:107-110.

21. Cruz-Filho AM, Paula EA, Pécora JD, Sousa-Neto MD. Effect of different EGTA concentrations on dentin microhardness. Braz Dent J 2002;13:188-190.
22. Reis C, De-Deus G, Leal F, Azevedo E, Coutinho-Filho T, Paciornik S. Strong effect on dentin after the use of high concentrations of citric acid: an assessment with co-site optical microscopy and ESEM. Dent Mater 2008;24:1608-1615.

23. Rhazi $M$, Desbrières $J$, Tolaimate $A$, Rinaudo $M$, Vottero $P$, Alagui A, et al.. Influence of the nature of the metal ions on the complexation with chitosan. Application to the treatment of liquid wast. Eur Polym J 2002;38:1523-1530.

24. Blair HS, Ho TC. Studies in the adsorption and diffusion of ions in chitosan. J Chem Technol Biotechnol 1981;31:6-10.

25. Domard A. pH and c.d. measurements on a fully deacetylated chitosan: application to CuII-polymer interactions. Int J Biol Macromol 1987;9:98-104.

Received March 11, 2012 Accepted April 13, 2012 